\title{
НАВАНТАЖЕННЯ І ДЕФОРМАЦІЇ ЗАЛІЗОБЕТОННИХ БАЛОК, ПІДСИЛЕНИХ ГНУЧКОЮ ЗОВНІШНЬОЮ АРМАТУРОЮ
}

\section{LOADING AND DEFORMATIONS OF REINFORCED CONCRETE BEAMS STRENGTHENED WITH FLEXIBLE EXTERNAL BARS}

Чеканович М.Г., к.т.н, проф., ORCID ID: 0000-0002-9110-4109, Романенко С.М., ст. викладач, ORCID ID: 0000-0002-0443-3896, Андрісвська Я.П. аспірант, ORCID ID: 0000-0003-3052-2515 (Херсонський державний аграрний університет)

Chekanovich M.G., candidate of technical sciences, professor, ORCID ID: 0000-0002-9110-4109, Romanenko S.M. senior lecturer, ORCID ID: 00000002-0443-3896, Andrievska Y.P. post-graduate student, ORCID ID: 00000003-3052-2515

В статті наведено результати експериментальних досліджень залізобетонних балок, підсилених новою конструктивною системою, що включає зовнішню сталеву арматуру. Конструкція розтягує безпосередньо верхню стиснуту під навантаженням зону балки i забезпечує високу її несучу здатність та знижує деформації, прогин.

Strengthening of reinforce-concrete structures is one of the most promising directions in the practice of reconstruction and building which allows getting a considerable technical and economic effect. A new system of strengthening of reinforced concrete beams has been developed. The system of strengthening includes a tie and external transversal bars. Transversal bars have a broken contour. Such a contour reduces stress in transversal bars and increases the efficiency of the system of strengthening.

Two series of twin beams have been experimentally studied. These beams had an identical reinforcement framework and were made from one and the same batch of concrete. The beams of the reinforced series are strengthened with external bars. Laboratory research on the loading - deformations dependence in beams was also conducted. The loading pattern envisaged load application at the third-points of beam span. Fibre deformations and beam deflection were determined. Crack initiation and crack width were registered in the concrete of beams.

Loading was increased until beam failure. As a result of measurements there were built load - deflection - fibre deformations plots. The effect of strengthening system was evaluated. The application of the proposed system 
of strengthening allowed increasing the bearing capacity of beams up to four times. Beam deflection was significantly reduced. Crack resistance of beams has been enhanced.

The proposed system of strengthening reinforced concrete beams can be effectively used in the process of reconstruction and building.

Ключові слова: Затяжка, напруження, деформації, міцність, залізобетонна балка, підсилення, зовнішня сталева арматура, несуча здатність.

tie, stress, deformations, strength, reinforced concrete beam, strengthening, external steel bars, bearing capacity.

Вступ. Реконструкція та капітальний ремонт - це основні види будівництва, де застосовується посилення несучих конструкцій в зв'язку надбудовою, перебудовою, розширенням, а також 3 заміною та (або) відновленням несучих будівельних конструкцій. Посилення конструкцій виконується також через втрату несучої здатності, що знизилася від фізичного зносу в процесі експлуатації, перевантаження, нерівномірного осідання фундаментів, пожежі і т.п. Зазвичай посиленню підлягають несучі конструкції, які розташовані в торгових, складських i виробничих приміщеннях у зв'язку 3 технічним переозброєнням чи модернізацією виробництва.

На виробництвах 3 часто змінюваним технологічним обладнанням проектування конструкцій підсилення здійснюють з урахуванням можливості подальшого збільшення навантажень. При новому будівництві посиленню підлягають конструкції в зв'язку зі змінами проектних рішень або ж через порушення стандартів якості використовуваних будівельних матеріалів.

Аналіз останніх досліджень. Підсилення залізобетонних конструкцій $\epsilon$ одним 3 найбільш перспективних напрямків в практиці реконструкції i дозволяє одержати значний техніко-економічний ефект. На сьогоднішній день існує значна кількість традиційних методів підсилення залізобетонних конструкцій.

В працях Голишева О.Б., Ткаченко I.Н., Хило Е.Р., Поповича Б.С., Шагина О.Л., Гвоздєва О.О., Онуфрієва Н.М., Стороженка Л.М. приділялась увага збільшенню поперечного перерізу конструктивних елементів, що характеризується збільшенням власної ваги конструкції [1-4].

Влаштування допоміжних конструкцій у вигляді зовнішніх тяжів, поясів, підпірних стійок, шпренгелів призводить до змін архітектурного виду будівлі та значним витратам матеріальних ресурсів та часу. Це досліджували і запропонували нові методи підсилення Сгоров В.В., Алексашкін С.Н., Божко В.А., Білозір B.В., Yoshida, E., Murakoshi, J., Tanaka Y., Okamura H., Higai T., Baluch, M. H., Ziraba, Y. N., Azad A. K., Sharif A. M., Irwin C.F., Roberts T. M., Wörner R., Schäfer H.G. [5-6].

Підсилення конструкцій полімербетоном, фібробетоном, шляхом приклеювання до розтягнутої або стиснутої зони конструкції таких 
ефективних матеріалів як вуглеволокно займались вітчизняні та, зокрема, німецькі вчені: Климпуш М. Д., Кваша В. Г., Мельник I. В., Мурин А.Я. [6], Конончук О.П., Борисюк О.П., Eberline D.K., Klaiber F.W., Dunker K., Basler M., Labossière P., Scherer H.G., Curbach M., Jesse F. [8], Offermann P., Hausding J., Köckritz U. [7].

Постановка мети і задач досліджень. Метою роботи $\epsilon$ ефективне зміцнення залізобетонних згинаних елементів новою системою розтяжок та дослідження напружено - деформованого стану таких згинальних елементів.

Для досягнення зазначеної мети сформульовані задачі дослідження:

1. Удосконалити нову систему підсилення залізобетонних елементів шляхом раціонального розташування затяжок (стрижнів) і встановлення обгрунтованого їх перерізу;

2. Провести експериментальні дослідження несучої здатності i деформативності залізобетонних елементів 3 пропонованою системою підсилення з сталевими затяжками і поперечними стрижнями.

3. Оцінити ефект від застосування залізобетонних балок, підсилених поздовжньо-поперечною зовнішньою системою 3 поперечними стрижнями ламаного контуру.

Методика досліджень. Проведенні експериментальні дослідження. 3 одного складу бетонної суміші було виготовлено дві серії дослідних зразків залізобетонних балок, куби з ребром завдовжки 100 мм та 150 мм, призми. Усі зразки-куби і призми були випробуванні у розрахунковому віці на стиск. Згідно ДСТУ Б В.2.7-214:2009 визначали міцність бетону на стиск, як статистично обгрунтоване значення за результатами випробування серії 3 трьох зразків. Міцність бетону на стиск склала - 35 МПа. Результати визначення міцності бетону оцінювались згідно з ДСТУ Б В.2.7-224. Клас бетону за міцністю на стиск - С20/25.

Випробувалось дві серії основних дослідних зразків балок. Серія звичайних залізобетонних балок позначалася маркуванням - БО-ІІ-1 (2). Серія підсилених зовнішньою системою залізобетонних балок маркувалася як БП-IV-1 (2). Зовнішня система підсилення була виготовлена згідно патенту [8].

Залізобетонні балки виготовлялися у лабораторії «ЛБМіК» довжиною 2100 мм з розмірами поперечного перерізу $200 \times 100$ мм. Просторовий каркас залізобетонної балки виготовлений з гладкої арматури діаметром Ø6А240С. Довжина каркасу 2080 мм, ширина 80 мм, висота 180 мм. Поперечне армування каркасу виконано з арматури діаметром Ø6 А240С з кроком 110 мм на чверть довжини балки. До арматурного каркасу до початку бетонування були приварені закладні деталі.

Залізобетонні балки серії БП-IV були посилені шляхом встановлення зовнішньої системи, яка містить затяжку, закріплену по кінцях на балці, взаємодіючу посередині з натяжним елементом, що обпирається на нижню грань балки, і поперечну зовнішню арматуру, взаємодіючу у приопорних 
зонах балки 3 верхньою i нижньою іiі гранями, а в середній частині взаємодіючу з затяжкою. Поперечні стрижні підсилення та затяжка виконані 3 арматури періодичного профілю Ø8 А400С. Діаметр котка посередині прольоту прийнято $\mathrm{d}_{\mathrm{k}}=55 \mathrm{~mm}$. Схема підсилення залізобетонної балки БП-IV -2 представлена на рис. 1.1. Тут верхня частина поперечних стрижнів ламаного профілю розташована під кутом $65^{\circ}$, а нижня - $15^{\circ}$ до горизонталі.

Зразки випробовувалися після досягнення бетоном проектної міцності, але не раніше, ніж через 28 діб після бетонування. Балки завантажували за допомогою гвинтового домкрату та розподільчої траверси двома зосередженими силами, які були прикладені до верхньої грані балки в третинах прольоту.

Значення зусиль визначали за допомогою тарованих кільцевих динамометрів. Розрахунковий проліт балки склав 2000 мм. Прогини балок фіксували за допомогою індикаторів годинникового типу, які кріпилися на спеціальну металеву рамку.

Протягом проведення експерименту спостерігали за тріщиноутворенням. Утворення тріщин виявляли візуально і за допомогою мікроскопа МПБ-2, за допомогою якого також визначали ширину розкриття тріщин. Відліки за індикаторами, динамометрами та фіксацію тріщин проводили після кожного ступеня навантаження після витримки до 15 хв..

Схема випробування балок серії БО-ІІ традиційна 3 симетричним навантаженням у третинах прольоту балки. Вага балки БО-ІІ-1 з обладнанням склала 117,3 кг. При проведенні експерименту появу перших тріщин в нижній розтягнутій зоні балки зафіксовано при навантаженні 5,03 кН. При навантаженні 5,12 кН в балці значення розкриття тріщин було близьким до 0,5 мм. Перед руйнуванням ширина розкриття тріщини, що знаходилася по середині балок, досягала - 4,0 мм. Руйнування балки відбулося по арматурі розтягнутої зони в зоні чистого згину при навантаженні 5,35 кН.

Схема випробування та загальний вигляд випробування балки БП-IV-2 показані на рис. 1.1 і на рис. 1.2 у вигляді фотографії. Поперечні стрижні використані у системі підсилення ламаного контуру.

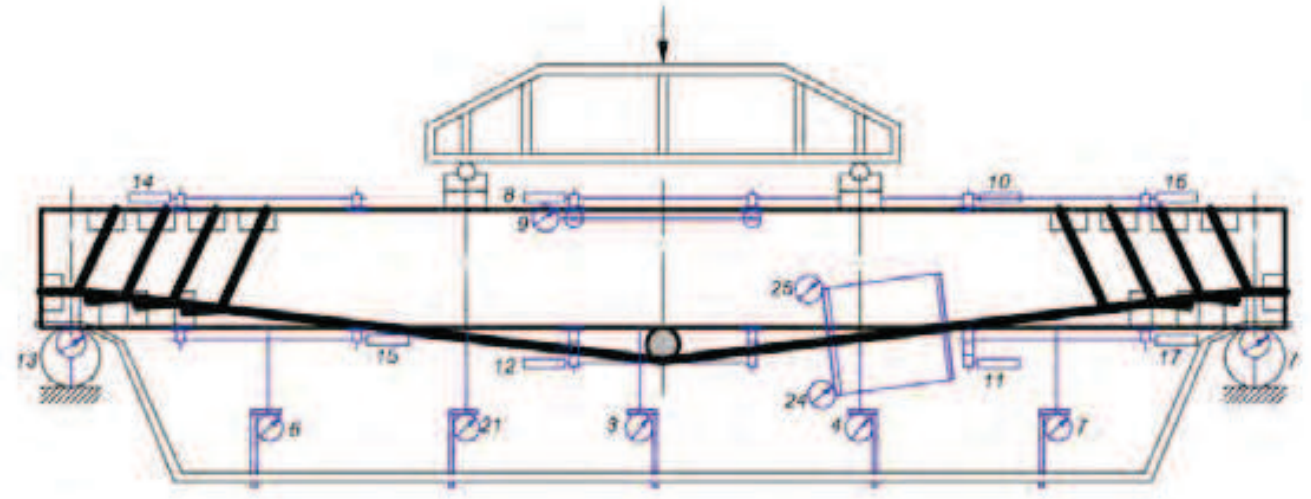

Рис. 1.1. Схема підсилення і випробування балки БП-IV-2 


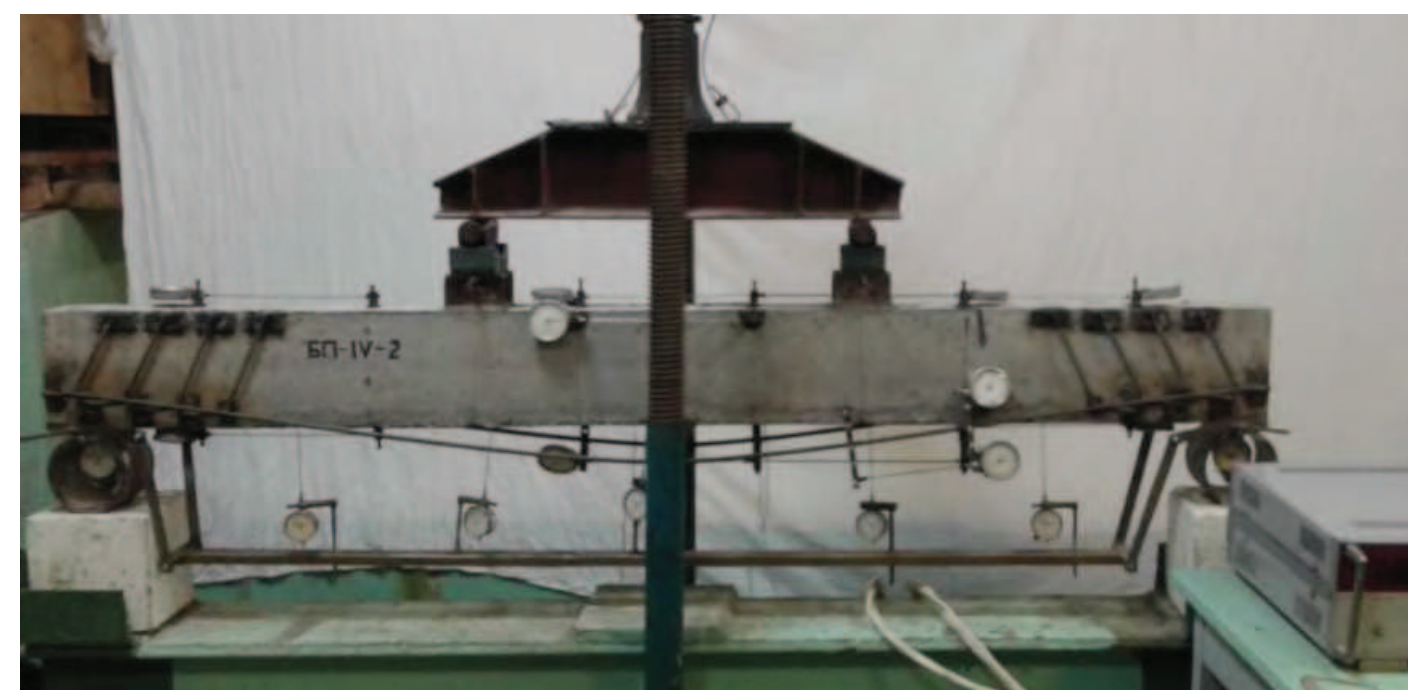

Рис. 1.2. Загальний вигляд випробування балки БП-IV-2

Після кожного ступеня навантаження визначалася ширина розкриття тріщин 3 визначенням тріщини 3 максимальним розкриттям. Утворення перших тріщин в нижній розтягнутій зоні балки зафіксовано при навантаженні 8,3 кН. При збільшенні навантаження виникали нові тріщини і зростала ширини розкриття існуючих тріщин. Перед руйнуванням ширина розкриття максимальної тріщини складала 1,2 мм. При значенні максимального розкриття тріщини 0,5 мм навантаження склало 14,25 кН. В результаті подальшого навантаження руйнування відбулося через вичерпання несучої спроможності системи підсилення балки. Максимальне зафіксоване навантаження, що витримала підсилена балка склало 21,5 кН.

Результати досліджень. На основі даних експериментальних досліджень були побудовані загальні діаграми фібрових деформацій бетону і прогинів по середині прольоту дослідних балок (рис. 1.3 і рис. 1.4).

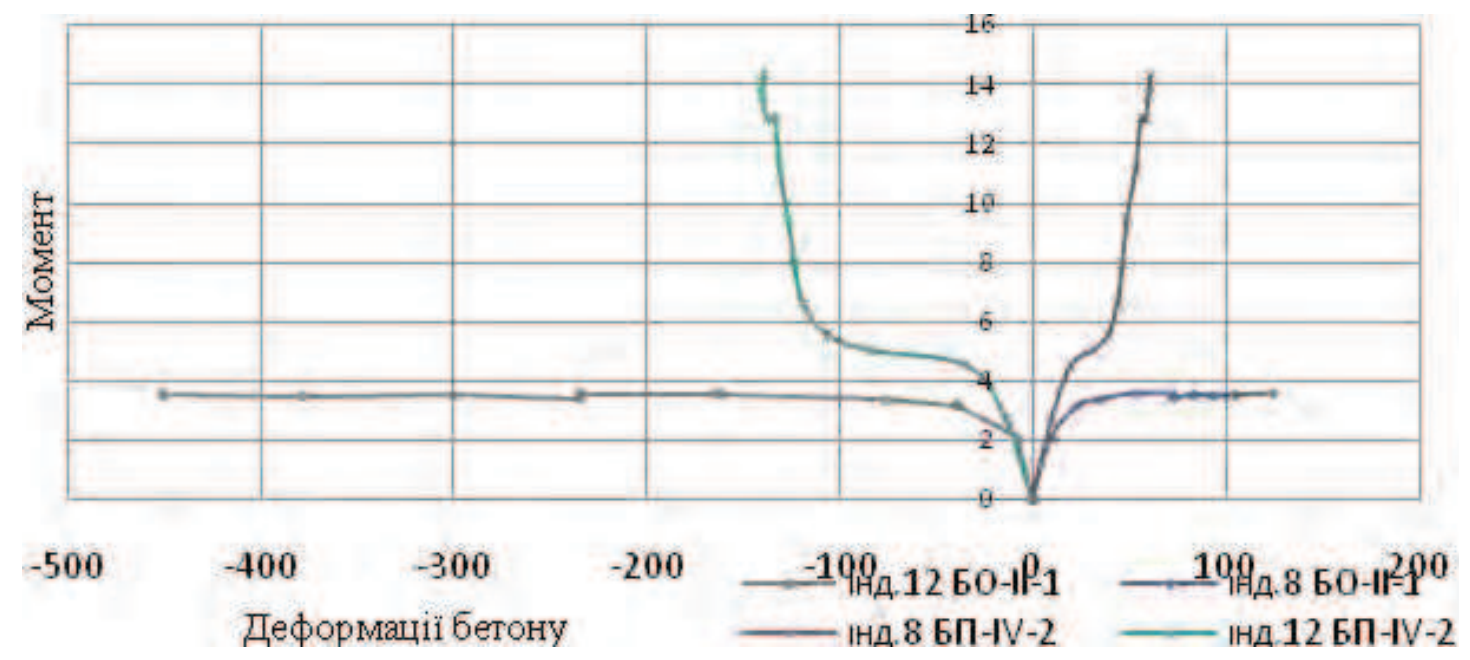

Рис. 1.3 Діаграми фібрових деформацій бетону по середині прольоту балок 


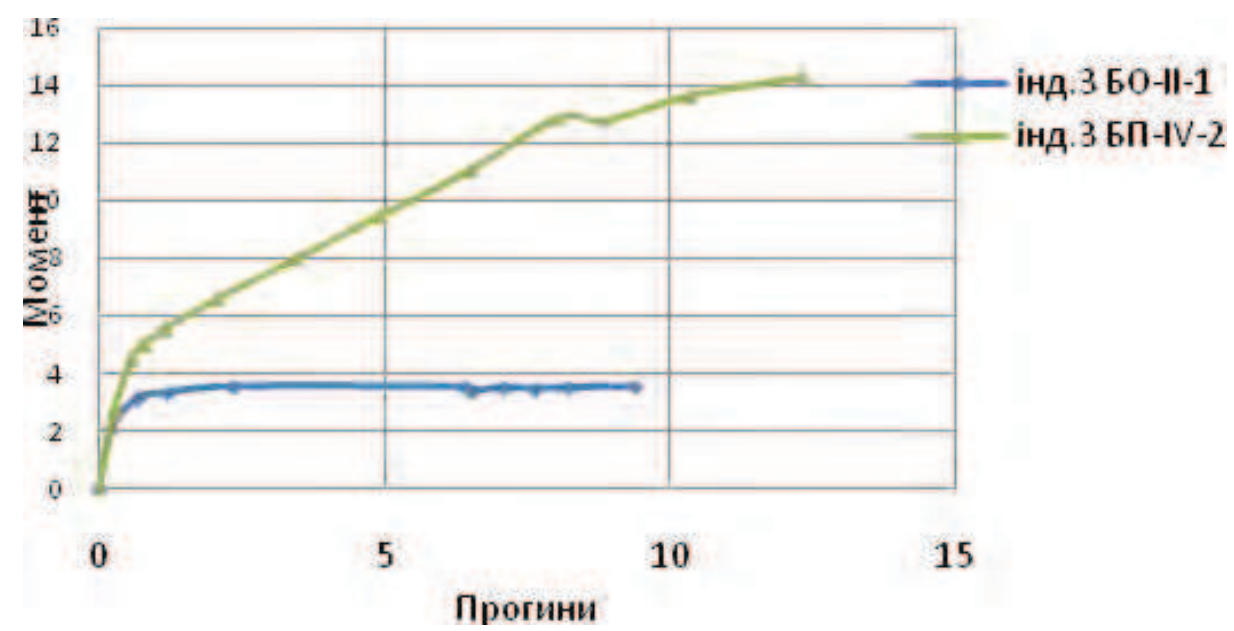

Рис. 1.4. Діаграма залежності «прогин - згинальний момент» для звичайної та підсиленої балок

Під час випробовування підсиленої балки серії БП-IV на поздовжній арматурі було встановлено два індикатори годинникового типу на спеціальних тримачах. Після обробки результатів, отриманих у ході експерименту, було побудовано графік залежності деформацій арматури від прикладеного згинального моменту до балки. Графік представлений на рис. 1.5 .

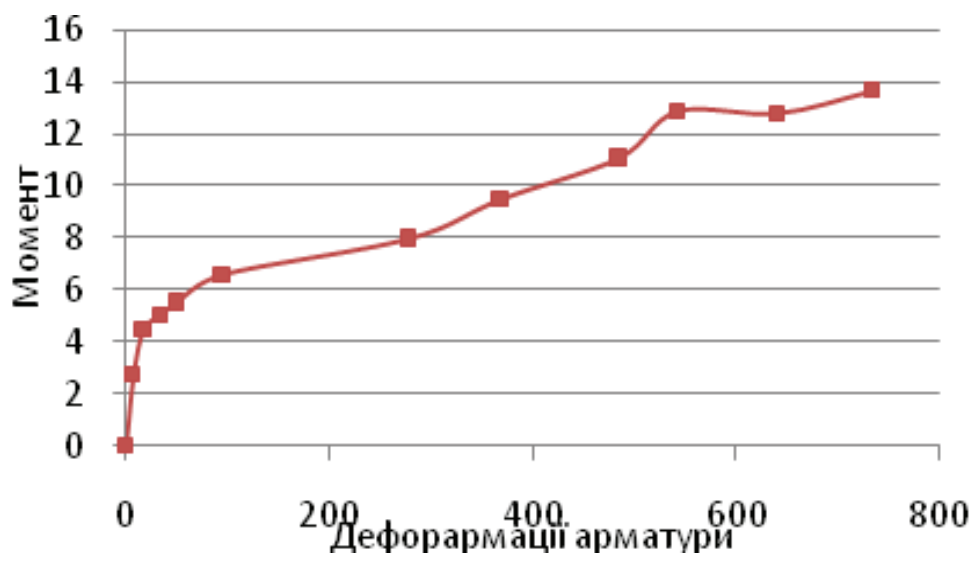

Рис. 1.5. Графік деформацій арматури за результатами вимірювань балки БП-IV-2

Висновки. Отримані експериментальні дані залежності навантаження i деформацій залізобетонних балок, підсилених зовнішньою системою 3 поперечними стрижнями ламаного контуру. Їх несуча здатність характеризується максимальним згинальним моментом, що склав: для звичайних балок - M=3,57 кН·м, а для підсилених - $\mathrm{M}=14,33 \mathrm{\kappa H} \cdot \mathrm{м}$.

За результатами випробування підсилених і звичайних балок встановлено, що залізобетонні балки підсиленої серії БП-IV витримали навантаження близько чотирьох разів більше, ніж звичайні балки серії БО-ІІ. Деформативність підсилених балок була значно меншою порівняно 3 еталонними звичайними балками. 
Таким чином, підсилення поздовжньо-поперечною зовнішньою системою $\epsilon$ ефективним засобом, у результаті якого значно підвищується несуча здатність балок та зменшується їх деформативність.

1. Голышев А.Б., Ткаченко И.Н. Проектирование усилений несущих железобетонных конструкций производственных зданий и сооружений. - К.: Логос, 2001.- $172 \mathrm{c}$.

2. Онуфриев Н.М. Усиление железобетонных конструкций промышленных зданий и сооружений. - Ленинград, 1965. - 342 с.

3. Шагин, А.Л. Локальное предварительное напряжение железобетонных и сталежелезобетонных конструкций / А.Л. Шагин // Юбилейные научные чтения по проблемам теории железобетона. Наука, технологии, производство: сб.тр. - М.: МИКХиС, 2009. - С. $107-116$.

4. Клименко С.В. Технічна експлуатація та реконструкція будівель і споруд: навчальний посібник/ Є.В. Клименко. - К.: Центр навчальної літератури, 2004. - С. 171

5. Пат. 85533 Україна, МПК Е04С 3/02 (2006.01). Залізобетонна балка. / Білозір В.В.; Львівський національний аграрний університет - № u 2013 05757, заявл. 07.05.2013; опубл. 25.11.2013.

6. Мурин А. Я. Міцність, жорсткість і тріщиностійкість залізобетонних балок, підсилених зовнішньою композитною арматурою: дис. канд. техн. наук: 05. 23. 01 / А. Я. Мурин. - Львів, 2011. - 163 с.

7. $\quad$ Curbach M.; Jesse F.: Verstärken mit Textilbeton. In: Betonkalender 99 (2010), T. 1, Berlin : Ernst \& Sohn, S. 457-565

8. Патент № 87047 Україна, МПК Е04С3/00. Регульованообтиснена залізобетонна балка/ Чеканович М.Г.; заявник і патентовласник: Чеканович М.Г №a 200710856; заявл. 01.10.2007; опубл. 10.06.2009, Бюл. № 11

1. Golishev A.B, Tkachenko IN Design of reinforcement of bearing structures of reinforced concrete industrial buildings and sooruzheniy.-K:. Logos, 2001.- S. 172

2. Onufriev N.M Strengthening of reinforced concrete structures of industrial buildings and structures. - Leningrad, 1965. - S. 342

3. Shahin, A.L Local prestressed concrete and composite structures / AL Shahin // Jubilee Scientific Conference on the issues of reinforced concrete theory. Science, technology, and production: sb.tr. - M .: MIKHiS 2009. - S. 107 - 116.

4. Klimenko C.V. Tehnichna ekspluatatsiya that rekonstruktsiya budivel i sporud: The Teaching posibnik / C.V. Klimenko. - K .: Center navchalnoï literaturi, 2004. - S. 171

5. Pat. 85533 Ukraina, MPK E04C 3/02 (2006.01). Zalizobetonna balka. / Bilozir V.V.; Lvivskyi natsionalnyi ahrarnyi universytet - № u 2013 05757, zaiavl. 07.05.2013; opubl. 25.11.2013.

6. Muryn A. Ya. Mitsnist, zhorstkist i trishchynostiikist zalizobetonnykh balok, pidsylenykh zovnishnoiu kompozytnoiu armaturoiu: dys. kand. tekhn. nauk: 05. 23. 01 / A. Ya. Muryn. - Lviv, 2011. - $163 \mathrm{~s}$.

7. Curbach M.; Jesse F.: Verstärken mit Textilbeton. In: Betonkalender 99 (2010), T. 1, Berlin : Ernst \& Sohn, S. 457-565

8. Patent number 87047 UKRAINE, IPC E04S3 / 00. Regulovanoobtisnena zalizobetonna bar / Chekanovich MG .; zayavnik i patentovlasnik: Chekanovich MG - Wa 200710856; appl. 01.10.2007; publ. 10.06.2009, Bull. Number 11. 